\title{
JUVENILE DELINQUENCY IN JAY ASHER'S NOVEL THIRTEEN REASONS WHY
}

\author{
Alda Dwi Afangka, Purwarno Purwarno \\ Faculty of Literature \\ Universitas Islam Sumatera Utara (UISU), Medan, Indonesia \\ E-mail: aldadwiaf@gmail.com
}

Received: 2021-04-27

Accepted: 2021-05-24

\begin{abstract}
This study is aimed at analyzing juvenile delinquency in Jay Asher's novel, Thirteen Reasons Why, published in 2007. Further, the analysis is focused on the forms of juvenile delinquency covering bullying, drinking alcohol, having free sex, and having sexual harassment done by the characters of the novel named Hannah Baker, Bryce Walker, Justin Foley, Alex Standall, Jessica Davis, Courtney Crimsen, Marcus Cooley, and Bryce Walker. This research is conducted to reveal the forms of juvenile delinquency conducted by the main characters in the novel. This study is qualitatively carried out. In this study, the researchers apply the theory of juvenile delinquency proposed by Santrock, supported by that proposed by Kartono referring to a variety of behavior of children and adolescents which the society does not approve and for which some kind of admonishment, punishment, or preventive and corrective measures are justified in the public interest. The research results show that the forms of juvenile delinquency: bullying, drinking alcohol, having free sex, and having sexual harassment are vividly reflected and clearly done by the main characters in the novel.
\end{abstract}

Keywords: juvenile, delinquency, bullying, drinking alcohol, free sex, sexual harassment

\section{Introduction}

Thirteen Reasons Why is a novel written in 2007 by Jay Asher. Jay Asher is an American writer and novelist, born in Arcadia, California, on September 30, 1975. He attended Cuesta Community College and later California Polytechnic State University in San Luis Obispo, before leaving during his junior year to pursue his career as a writer. Asher spent years trying to kick-start a career writing children's picture books. During this time, Asher worked at a shoe store, a trophy shop, libraries, and bookstores.

Asher has published four books: Thirteen Reasons Why, a 2007 New York Times best-selling fiction novel; The Future of Us, co-written by Carolyn Mackler; What Light; and Piper. Asher has also written several picture books and middle school humor novels. Thirteen Reasons Why won several awards and received five stars from Teen Book Review. It also received high praise from Ellen Hopkins, Sherman Alexie, Chris Crutcher, and Gordon Korman. Asher's novel, Thirteen Reasons Why, was considered for a film treatment with Selena Gomez starring. Netflix released a series 
based on the novel on March 31, 2017, with Selena Gomez serving as executive producer.

Thirteen Reasons Why is a story of Hannah Baker, a girl who dies by suicide. She reveals her thirteen reasons for her decision in a series of several audio tapes mailed to a classmate with instructions to pass them from one student to another, in the style of a chain letter. Through Hannah's recorded voice, her classmates learn the reasons why Hannah decides to take her own life. Besides Hannah, the reader also sees the story through the eyes of Clay Jansen, one of the recipients of the tapes. Hannah is introduced as a sophomore at the fictional Liberty High School, characterized by her struggle adjusting to life in an unsympathetic school environment and various social problems that are most often faced by adolescents and society today such as juvenile delinquency. A form of juvenile delinquency such as sexual harassment is experienced by Hannah, which results in her being raped at the first party she attends. Hannah tries to fight back but it is in vain. The novel has a great story that contains the values of daily life. The readers can take the lessons about juvenile delinquency from the experiences of the characters in the novel.

Tied to the juvenile delinquency, Santrock (2007) states that juvenile delinquency is driven from a variety of adolescent attitudes that cannot be accepted in society, that is why, they cause to criminal behaviors. In line with Santrock (2007), Kartono (2014) claims that juvenile delinquency is an indication of social pathology in adolescent that is caused by a shape of social carelessness. Springer and Roberts (2011) claim that the problems of Juvenile Delinquency have got attention from society especially since it was organized as Juvenile Court in 1899, in Illinois, United States.

The writers feel interested in analyzing juvenile delinquency in Asher's Thirteen Reasons Why since in this novel Asher has stunningly reflected the story of Hannah Baker committing suicide with thirteen reasons in audio tapes. Of the thirteen reasons, some of them are noticeably due to juvenile delinquency. This research is focused on the juvenile delinquency because it has become a problem in every country. It has long been a problem why some children steal, drink alcohol, bully other children, rob, play truant, set fires, damage property, etc., causing serious effects on the victim, committing suicide. Juvenile delinquency has also increased years to years especially in the internet era in which any information and adult sites or videos can be freely accessed online by the youngsters. Moreover, many parents are ignorant to the development of their children as well as to the unfavourable atmosphere for children, which surely contribute to the juvenile delinquency. Therefore, the writers believe that this topic will be useful for the readers especially for the youngsters as well as the parents since in this research, some recommendations how to prevent and solve the problems due to juvenile delinquency are presented.

\section{Literature Review}

\subsection{Juvenile Delinquency}

Juveniles are young people who are in the transitional period. According to Steinberg (1990) adolescence is a transitional period of development from childhood to adulthood with evident biological and emotional changes. These changes bring transformation and reorganization in the family relationship. According to Monks et.al (2004), adolescence globally takes place between the ages of 12 and 21 years, with the division of 12-15 years being early adolescence, 15-18 years being mid-adolescence, and 18-21 years being late adolescence. 
Delinquency from a legal perspective refers to any behavior that violates the criminal law, committed by a young person below the age of eighteen. Depending on the nation of origin, a juvenile becomes an adult anywhere between the ages of 15 to 18 , although the age is sometimes lowered for murder and other serious crimes.

Offenses or crimes committed by juveniles range from minor to major indexed crimes such as petty theft, traffic violation, drug abuse and/or trafficking, robbery, and crimes that cause grievous hurt to other persons. This definition of delinquency is in line with Bartollas' (2003: 8) definition, in which he says, that delinquency is typically defined as an act committed by a minor that violates the penal code of the government with authority over the area in which the act occurs.

According to Kartono (2014), juvenile delinquency is evil behavior or crime/delinquency of young children; a symptom of social (pathological) illness in children and adolescents caused by a form of social neglect, so that they develop a form of deviant behavior. According to Sarwono (2011), juvenile delinquency is all behavior that deviates from the norms of criminal law.

According to Gold and Petronio in Sarwono (2011), juvenile delinquency is an act by an immature person who deliberately violates the law and what the child knows if his act is known by legal officers he can be subject to punishment. Sudarsono (2012) states that juvenile delinquency is not only an act of children who violate the law but also includes acts that violate the norms of society.

Salagaev (2003: 189) says, "Juvenile delinquency is criminal behaviors among young people, as they negotiate the transition from childhood to adulthood in an increasingly complex and confusing world." Mussen et.al (1994) defines juvenile delinquency as unlawful behavior or crime that is usually committed by adolescents aged 16-18 years, if the act is committed by an adult then it will get legal sanctions.

Santrock (2003) claims that juvenile delinquency can be divided into three, namely:

1. Actions that are not acceptable to the social environment because they are against the values and norms of society, for example speaking harshly to teachers and parents, etc.

2. Actions of minor violations such as skipping school, running away at certain subject hours, etc.

3. Serious offenses that refer to all criminal acts committed by youth, such as stealing, premarital sex, using illegal drugs, etc.

The opinion regarding the forms of juvenile delinquency put forward by Santrock (2003) is in line with the daily phenomena. It consists of actions that are not acceptable to the social environment, acts of minor violations, and serious violations.

In line with Santrock, Kartono (2014: 21-23) argues that the forms of juvenile delinquency are as follows:

1. Speeding on the road that can hurt other drivers.

2. Disrupting the peace of the environment.

3. Fighting between gangs, school, and groups that can cause casualties.

4. Skipping schools is only for hiding in remote place (stalls) or just wandering along the road.

5. Committing acts of violence on others.

6. Drinking alcohol that can disturb the environment and having sex.

7. Raping. 
8. Being addicted to illegal drugs.

9. Doing sexual acts without shame.

10. Doing sadistic actions.

11. Gambling and other forms of bets.

12. Aborting as the results of free sex.

13. Doing abductions and killings.

14. Committing anti-social acts caused by psychiatric disorder.

15. Crimes can also be caused by injuries to the head with damage to the brain sometimes resulting in mental damage, so that the person concerned is unable to exercise self-control.

16. Deviation of behavior caused by damage of character.

More and more forms of juvenile delinquency are caused by the times as well as the rapid development of technology. The form of juvenile delinquency can be in the forms of skipping school, smoking, fighting, stealing, watching pornographic films, drinking alcohol, sex outside of marriage, using illegal drugs, raping, gambling, killing, street speeding, and many others.

\subsubsection{Bullying}

Juvonen, and Graham (2014) states that bullying is the use of force, , coercion or threat, to, abuse, aggressively dominate or intimidate. The behavior is often repeated and habitual. One essential prerequisite is the perception (by the bully or by others) of an imbalance of physical or social power. This imbalance distinguishes bullying from conflict.

Bullying is one of the most common social problems that teenager and society face today as out of ten teenagers might have experienced bullying in their life whether they are as a victim or as a bully.

Smith (2002), says "Bullying is unwanted, aggressive behavior among school aged children that involves a real or perceived power imbalance. The behavior is repeated, or has the potential to be repeated over time. Both kids who are bullied and who bully others may have serious, lasting problems". In order to be considered bullying, the behavior must be aggressive and include: An Imbalance of Power: Kids who bully use their power such as physical strength, access to embrassing information, or popularity to control or harm others. Power imbalances can change over time and in different situations, even if they involve the same people. Bullying includes actions such as making threats, spreading rumors, attacking someone physically or verbally, and excluding someone from a group on purpose.

\subsubsection{Drinking Alcohol}

Drinking alcohol can have serious consequences for teenagers and drinking underage is illegal. Underage drinkers may face social problems such as education, family problems, and physical problems. In addition, consuming alcohol in the short term can make adolescents poisoned and even cause death. Meanwhile, in the long term, there is a possibility that adolescent will become addicted.

\subsubsection{Having Free Sex}

Free sex is an activity that is carried out together at a time and place that has been mutually agreed upon by two other types of people who are not married. Free sex 
behavior is sexual activity that is done outside of marriage which is the same as adultery; this behavior is considered sexual behavior which becomes a social problem for society and the state because it is done outside marriage (Wahyuningsih, 2008).

According to Desmita (2012) the notion of free sex is all ways of expressing and releasing sexuality that comes from the maturity of sexual organs, such as intimate dating, making out, having sexual contact that are not in accordance with the norms because adolescents do not have sexual experiences. Furthermore, Kartono (1992) states that one form of free sex behavior is sexual intercourse which is carried out by changing partners with the aim of obtaining excessive sexual experiences.

\subsubsection{Having Sexual Harassment}

Sexual harassment refers to all comments or actions of a sexual nature or other behavior related to a person's gender that are unwanted by the person to whom they are directed, and which adversely affect their well-being. Sexual harassment is a form of discrimination (defined in Article 4 of the Swiss Federal Act on Gender Equality).

It is important to highlight that sexual harassment is characterized not by the intention of the acting person, but rather by the way the targeted person perceives, receives or feels about this behavior. As such, even if an individual is neither aware nor deliberately attempting to inconvenience another person through their inappropriate sexual language or attitudes, sexual harassment may still occur.

Sexual harassment can occur independently of hierarchical relationships; it may come from an immediate superior, subordinates, work colleagues, students or any other person with whom an individual may be required to work or collaborate. Sexual harassment does not always have to be specifically about sexual behavior or directed at a specific person. For example, negative comments about women as a group may be a form of sexual harassment. Although sexual harassment laws do not usually cover teasing or offhand comments, these behaviors can also be upsetting and have a negative emotional effect.

\section{Research Method}

In conducting research, we need a research design. According to Creswell (2009: 3) research design is a plan and the procedures for research to detailed methods of data collection and analysis. The function of a research design is to ensure that the evidence obtained enables us to answer the initial question as unambiguously as possible. In this research, the researchers use the qualitative method. In the qualitative method, the analysis begins when the data are collected. This method explains the understanding of structure and pattern of the data, and observing the data to understand the phenomenon of what is experienced by the subjects of the research such as behavior, perception, motivation, and action (Moleong, 2007: 6).

Narrative researchers collect stories, documents, and group conversations about the lived and told experiences of one or two individuals. They record the stories using interviews, observation, documents, and images and then report the experiences and chronologically order the meaning of those experiences (Creswell, 2013: 72). Ary et.al. (2010: 424) states that qualitative inquirer deals with data that are in the form of words or pictures rather than numbers and statistics.

In analyzing the data, the writers need the data analysis procedures to show how the data collected are analyzed carefully. The data analysis procedures are classifying 
the data, analyzing the data carefully and accurately, and making the conclusion from the data analyzed.

\section{Discussion}

In this section, the writers analyse the juvenile delinquency conducted by the major characters in Jay Asher's novel, Thirteen Reasons Why. The analysis is focused on the forms juvenile delinquency covering bullying, drinking alcohol, having free sex, and having sexual harrasment.

\subsection{Bullying}

It all starts with Justin Foley and Hannah Baker who have an affinity for each other. As a young couple who feel attracted to each other, they have a date in the park and kiss. This event is clearly depicted in Asher (2007, p. 30), in which the existence of social bullying happens towards Hannah. Justin as the first man who kisses Hannah starts bragging to his friends that he and Hannah have done more than merely kissing. He has spread false news which is a cruel order against Hannah. He in fact has humiliated Hannah. Justin even brags to his friends that Hannah is a slut. Justin's bragging is the beginning of Hannah Baker's downfall since it makes Hannah get social bullying.

Hannah again gets social bullying from her classmates as it is vividly reflected on pages 39-40 of the novel. This time, the cause of her social bullying is due to one of her classmates by the name of Alex, who has boasted a list of papers with the title on the paper: FRESHMAN CLASS-WHO'S HOT/WHO'S NOT and then passes the paper to their classmates. Alex's list is actually a joke, and he never knows that the list will affect Hannah and her life. This gives people the opportunity to treat Hannah as if she were nothing but that specific body part. The rumors have made Hannah depressed, and she even decides to end her life.

\subsection{Drinking Alcohol}

Drinking alcohol is a form of social deviation that occurs among adolescents. This section describes drinking alcohol that is done by the main characters in the novel. They are used to drinking alcohol at parties held by some of the students. The depiction of the event can firstly be seen on pages 206 and 207 in which it is stated that it is not for the first time for Hannah to have attended a party. For Hannah and her friends, drinking alcohol is what she most wants to do on weekends. Their habit of drinking alcohol in a long period of time has made them alcoholics. They do not realize that drinking alcohol has harmful effects on them as teenagers as it is reflected on page 221 as well.

Drinking alcohol has negative effects such as nausea, walking unsteadily, and even unconsciousness. This time, Jessica who has got drunk due to drinking too much could not walk well. That opportunity is made use by Justin to bring Jessica into a room and start kissing her, "Instead of leaving, he started kissing her." (Asher, 2007: 222)

\subsection{Having Free Sex}

The next form of juvenile delinquency depicted in the novel is having free sex. Free sex is a sexual activity performed outside of marriage. This behavior is considered 
sexual behavior which is a social problem for society and the state. Hannah Baker and Bryce Walker are at the party held at Courtney's house, and they enter the hot tub there. That night Hannah allows herself to be touched by Bryce. Inside the hot tub, Hannah does nothing to stop Bryce. She even knows exactly what Bryce is doing to her. Hannah does not say "no" or push his hands away. All she does is turning her head, clenching her teeth, and fighting back tears. It is clearly depicted in Asher (2007: 265), "As if leting him finger me was going to cure all my problems. But in the end, I never told you to get away ... and you didn't"

Bryce and Hannah have made love. They have done free sex. It impliedly reveals that free sex activities have become commonplace in interactions between teenagers without thinking about the consequences of their actions. They think that sex outside of marriage is a common thing since they never realize that free sexual life will pose a number of substantial dangers.

Teenagers who have become sexually active at a young age are more likely to become depressed or attempt suicide; they are more exposed to different kinds of sexual and intimacy disorders, emotional addictions, abusive relationships, and so on. Such teens are also at risk of becoming pregnant too early, or becoming infected by a Sexually Transmitted Disease (STD) which constitutes infections that are transmitted during vaginal, anal, and oral sex. Therefore, teenagers should be explained the respective dangers, and parents should pay more attention to their children's behavior and health.

\subsection{Having Sexual Harrasment}

Sexual harassment refers to all comments or any sexual-related behaviors, speeches, gestures, or approaches that are unwanted by the person to whom they are directed, and which adversely affect their well-being. Sexual harrasment is a form of descrimination. Marcus has sexually harassed Anna by caressing Hannah's knees with his fingertips. "And I couldn't look away as your fingertips caressed my knee . . . and started moving up." (Asher, 2007: 142) Hannah feels uncomfortable about Marcus Cooley's treatment on her. The attitude of Marcus that suddenly touches Hannah is the same way she is touched in the liquor store. "Your shoulder rotated and I lifted my head, but now your arm was behind my back and pulling me close. And your other hand was touching my leg. ... Below the table, my fingers were fighting to pry your fingers off. To loosen your grip. To push you away." (Asher, 2007: 142). The lines depicts that Marcus begins to wrap his arms behind Hannah's back and pull Hannah closer to her. At the same time, Marcus's fingers continue to touch Hannah's leg and begin to move up to Hannah's upper thigh. Hannah's fingers reach out to let go of Markus' fingers which are getting naughty on her upper thighs. This clearly shows that Hannah feels uncomfortable with Mark's treatment, but Markus continued his sexual harrasment. Even though several people around there watch them, they soon look away since they feel that is none of their business.

Marcus still continues his sexual harrasment to Hannah as if Hannah were a slut like the rumor that has been spread over among Hannah's friends. Hanna asks Marcus to stop his naughty actions, and she is rammed both of her hands into the sides of Marcus's body. Hannah throws Marcus to the floor and it makes the people around the cafe know that it is not an accident. They know something is going on in the cubicle. However, they do not make any attempt to to help Hannah. 
Juvenile Delinquency in Jay Asher's Novel Thirteen Reasons Why, Alda Dwi Afangka, Purwarno Purwarno

\section{Conclusion}

Based on the analysis of Juvenile Delinquency in the novel, some conclusions can be put forward. There are four forms of juvenile delinquency depicted in the novel namely bullying, drinking alcohol, having free sex, and having sexual harassment. Bullying is a delinquency that can be considered an ordinary acquaintance since it has serious impact on the victims and even if the victims cannot handle it and it is not uncommon for them to make the decision to commit suicide. Drinking alcohol under age has a negative impact on adolescents themselves, either in the short term or in the long term. It can make a person become an alcoholic. Free sex is considered as a social problem for the society and the state because it is done before marriage. It breaks social norms as well as religion law. Teens who have had free sex at a young age tend to become accustomed to doing it. This can have adverse effects which can lead to addiction to doing it, becoming depressed or attempting suicide. Apart from that they will also be exposed to various types of sexual and intimacy disorders, emotional addiction, abusive relationships, and so on. In addition, teenage girls are also at risk of getting pregnant too early, or even being infected with sexually transmitted diseases (STDs), which are infections that are transmitted during sexual intercourse.

The first character in this novel named Hannah Baker is the first female character in this novel who has been involved in juvenile delinquency. In this novel, Hannah is not the only one who has involved in juvenile delinquency, but her friends named Bryce Walker, Justin Foley, Alex Standall, Jessica Davis, Courtney Crimsen, Marcus Cooley, and Bryce Walker are also involved in juvenile delinquency. They are accustomed to having parties to drink alcoholic beverages which result in bullying, sexual promiscuity, and experiencing sexual harassment.

All forms of juvenile delinquency as stated in the scope of this research are vividly depicted in this novel. However, the character who experiences the worst effect of the juvenile delinquency in this research is the first character named Hannah, because in this story Hannah is told to have committed suicide as a bad result of the juvenile delinquency.

\section{References}

Ary, et.al. (2010). Introduction to Research in Education. Wadsworth: Cengange Learning.

Asher, Jay. (2007). Thirteen Reasons Why. New York: Razorbill.

Bartollas, C. (2003). Juvenile Delinquency. 6th ed. NY: Allyn \& Bacon.

Creswell, J. W. (2009). Research Design (Pendekatan Kualitatif, Kuantitatif, dan Mixed). Yogyakarta: Pustaka Pelajar.

Creswell, J. W. (2013). Research Design Pendekatan Kualitatif, Kuantitatif, dan Mixed, edisi ketiga. Yogyakarta: Pustaka Pelajar.

Desmita. (2012). Psikologi Perkembangan. Bandung: PT. Remaja Rosda Karya.

Juvonen, J., Graham, S. (2014). Bullying in Schools: The Power of Bullies and the Plight of Victims. Annual Review of Psychology. 65: 15985. doi:10.1146/annurev-psych-010213-115030. PMID 23937767. S2CID 207640520

Kartono, Kartini. (1992). Patologi Sosial 2 Kenakalan Remaja. Jakarta: Rajawali. Kartono, K. (2014). Patologi Sosial 2 Kenakalan Remaja. Jakarta: Rajawali Pers. Moleong, Lexy J. (2007). Metodologi Penelitian Kualitatif. Bandung: Remaja Rosdakarya Offset. 
Monks, et.al. (2004). Psikologi Perkembangan Pengantar dalam BerbagaiBagaiannya. Yogyakarta: UGM Press.

Mussen, P.H. et.al. (1994). Perkembangan Pada Anak. Jakarta: Arcan.

Salagaev, A. (2003). World Youth Report: The Global Situation of Young People, Juvenile Delinquency.

Santrock, John W. (2003). Adolescene Perkembangan Remaja. Jakarta: Erlangga

Santrock, J. W. (2007). Psikologi Perkembangan, Edisi 11 Jilid 1. Jakarta: Erlangga.

Sarwono. (2011). Psikologi Remaja. Jakarta: Rajawali Press.

Smith. (2002). Pseudoscience and Extraordinary Claims of the Bullying. New Jersey: Wiley-Blackwell.

Springer, David and Roberts, Albert. (2011). Juvenile Justice and Delinquency. New Jersey: Jones \& Bartlett.

Steinberg, L. (1990). Autonomy, Conflict, and Harmony in the Family Relationship. In S. Feldman \& G. Elliot (Eds.), At the threshold: The developing dolescent pp.255-276). Cambridge: Harvard University Press.

Sudarsono. (2012). Kenakalan Remaja. Jakarta: Rineka Cipta.

Wahyuningsih. (2008). Hubungan Antara Konsep Diri, Kontrol Diri dan Perilaku Seks Pra Nikah. http://rac.uii.ac.id (September 2020). 